\title{
The Problems of Conceptualization and Categorization in English Terminology
}

\author{
Svetlana V. Kiseleva ${ }^{1 凶}$, Marina Yu. Mironova ${ }^{1}$, Nella A. Trofimova ${ }^{2}$ \\ ${ }^{1}$ Saint Petersburg State University of Economics, St Petersburg, Russia \\ ${ }^{2}$ Higher School of Economics, St Petersburg, Russia

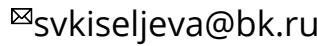

Introduction. The paper focuses on the linguistic concepts of terminology and a term system, provides the views of linguists on the definition and differentiation of these terms, explains the semantics of the word and the term, as well as the role of the cognitive approach in modern terminology. The scientific work defines a concept and a category, and describes the role of the processes of conceptualization and categorization in English terminology. As more than $90 \%$ of new words appearing in modern languages is vocabulary for special purposes, it is increasingly important to study the ways of their formation. The research is relevant since it provides a deeper understanding of the structure and content of concepts that underlie the formation of language categories, the mechanisms of interaction between cognitive and language structures in the process of forming the terminological meaning.

Methodology and sources. In light of the cognitive approach to understanding the semantics of a word the authors emphasize anthropocentrist thinking, language picture of the world and lexical-semantic variants of the word. The cognitive approach allows us to reveal the causes and mechanisms of dynamic processes in the field of professional nomination, taking into account the changing cognitive and communication needs of people. The research is made using corpora data.

Results and discussion. It has been found out, that cognitive categories are linked to conceptually defined prototypes that are crucial for the formation of categories. The necessary to define the central elements of prototypical categories has been proved, as they make the category logical, understandable and convenient, since all members of the category meet a given list of characteristics. As a result of the research it has been proved that in an investment terminological system a prototype turns out to be the best representative of a category.

Conclusion. It has been concluded that the study of conceptualization and categorization processes is extremely important when analyzing terminological systems in general, and investment terminological system of English, in particular, because it allows to identify the basic concepts underlying the formation of terminological systems. The study of the principles and mechanisms of categorization of language units makes it possible to identify and analyze their prototypical semantics in terms of their common properties with the prototype of the category. This possibility is of paramount importance for research in the field of cognitive linguistics, since it is the prototypical semantics of language units that largely determines their use in a sentence to convey a particular meaning.

Key words: terminology, a term system, a concept, a category, conceptualization, categorization, a prototype.

(c) Kiseleva S. V., Mironova M. Y., Trofimova N. A., 2020

Контент доступен по лицензии Creative Commons Attribution 4.0 License.

This work is licensed under a Creative Commons Attribution 4.0 License. 
For citation: Kiseleva S. V., Mironova M. Y., Trofimova N. A. The Problems of Conceptualization and Categorization in English Terminology. DISCOURSE. 2020, vol. 6, no. 2, pp. 115-124. DOI: $10.32603 / 2412-8562-2020-6-2-115-124$

Conflict of interest. No conflicts of interest related to this publication were reported.

\title{
Проблемы концептуализации и категоризации в терминологии английского языка
}

\author{
С. В. Киселёва ${ }^{1 凶}$, М. Ю.Миронова ${ }^{1}$, Н. А. Трофимова ${ }^{2}$ \\ ${ }^{1}$ Санкт-Петербургский государственный экономический университет, Санкт-Петербург, Россия \\ ${ }^{2}$ Высшая школа экономики, Санкт-Петербург, Россия

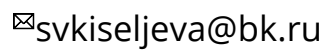

Введение. Статья посвящена лингвистическим понятиям терминологии и терминосистемы и рассматривает взгляды лингвистов на их определение и дифференциацию, объясняет семантику слова и термина, а также роль когнитивного подхода в современной терминологии. Дается определение понятия и категории, описывается роль процессов концептуализации и категоризации в английской терминологии. Исследование актуально, поскольку обеспечивает более глубокое понимание структуры и содержания понятий, лежащих в основе формирования языковых категорий, механизмов взаимодействия когнитивных и языковых структур в процессе формирования терминологического значения.

Методология и источники. В свете когнитивного подхода к пониманию семантики слова авторами сделан акцент на антропоцентрическом мышлении, языковой картине мира и лексико-семантических вариантах слова. Когнитивный подход позволяет выявить причины и механизмы динамических процессов в сфере профессиональной номинации с учетом меняющихся познавательных и коммуникативных потребностей людей. Исследование проводится на материале корпуса текстов Corpus of Contemporaty American English.

Результаты и обсуждение. Установлено, что когнитивные категории связаны с прототипами, которые имеют решающее значение для формирования категорий. Доказана необходимость выявления центральных элементов прототипических категорий, поскольку они делают категорию логичной, понятной и удобной, так как все члены категории отвечают заданному перечню характеристик. В результате исследования было доказано, что в инвестиционной терминологической системе прототип выступает наилучшим представителем категории.

Заключение. В результате исследования сделан вывод о том, что анализ процессов концептуализации и категоризации является чрезвычайно важным при изучении терминосистем языка в целом и инвестиционной терминосистемы английского языка в частности, поскольку позволяет выявлять базовые концепты, лежащие в основе формирования терминологических систем. Изучение принципов и механизмов системной и функциональной категоризации языковых единиц дает возможность выявить и проанализировать их прототипическую семантику с точки зрения их общих свойств с прототипом той категории, членами которой они являются. Эта возможность имеет первостепенное значение для исследований в области когнитивной лингвистики, поскольку именно прототипическая семантика языковых единиц во многом определяет их использование в предложении для передачи того или иного смысла. 
Ключевые слова: терминология, терминосистема, понятие, категория, концептуализация, категоризация, прототип.

Для цитирования: Киселёва С. В., Миронова М. Ю., Трофимова Н. А. Проблемы концептуализации и категоризации в терминологии английского языка // ДИСКУРС. 2020. Т. 6, № 2. С. 115124. DOI: $10.32603 / 2412-8562-2020-6-2-115-124$

Конфликт интересов. О конфликте интересов, связанном с данной публикацией, не сообщалось.

Поступила 18.02.2019; принята после рецензирования 11.03.2020; опубликована онлайн 27.04.2020

Introduction. The rapid growth of scientific and technical knowledge, constant changes in the social and economic fields, as well as the information revolution have led to the fact that today professional communication is becoming an object of active study of domestic and foreign scientists. New discoveries and achievements, exchange of experience and knowledge contribute to the intensive replenishment of the vocabulary of national languages due to the formation of new terms. More than $90 \%$ of new words appearing in modern languages is special vocabulary. The growth in the number of terms in various sciences is outpacing the growth in the number of commonly used words. Moreover, terms are beginning to actively penetrate the common vocabulary, and terminological problems have an impact on the entire language. That is why the most important thing for language development is to study the situation in the field of special vocabulary, and further development of communication requires unification and systematization of the terms used.

The second half of the 20th century is characterized by a strong development of terminological research, which led to the formation of a new science - terminology. Over time, terminology has grown into an independent discipline that combines such sciences as lexicology, philosophy, translation theory, linguistics and semiotics. Today, terminology is becoming increasingly attractive to researchers, and it is assigned one of the main places among modern scientific disciplines.

Terminology is a branch of science that explores the semantic nature, grammatical organization and laws of functioning of terminologies in various areas of human professional activity [1]. Terminology studies the patterns of development and use of special vocabulary, develops recommendations to address the shortcomings of creating, ordering, and using terms and terminologies [2].

Here it is necessary to distinguish the concepts of terminology and a term system. Terminology is the science that studies terms. The main object of terminology is a set of terms in a certain area of knowledge. Terminology is subject to systematization and analysis, which reveals its shortcomings and methods of their elimination. The results of this work are presented in the form of a term system.

A term system is a complex hierarchical structure consisting of words and phrases that perform the functions of terms - elements of the term system. At the same time, the integration of these lexical units into rows of the same level and into multi-level paradigms is carried out artificially, using logical methods of analysis and synthesis. Thus, we can say that the term system is a natural-artificial formation, where the material is natural, and the ways of its organization are artificial [2]. The term system is an ordered set of terms with fixed relations between them, reflecting the links between the concepts named by these terms. The term system 
is characterized by a linguistic and logical system, which allows us to speak of the term system as a language model of a particular area of study.

Methodology and sources. The works on streamlining and standardizing terminology began in the early 30s. More than 20 standards for terminology in various scientific and technical fields have been developed and approved. To ensure a unified methodological approach to standardization of terminology, a set of methodological materials has been created that regulate the procedure for developing and writing standards, compiling and maintaining terminological reference books. The methods formulate the following requirements for standardized terms: the term must be unambiguous, concise, systematic, correct from the point of view of linguistics, and derivative. However, state standards are not always used in the real language practice of specialists. This is largely due to the unexplored theoretical problems of terminology, namely, the difficulty of drawing the boundary between a term and a non-term, so the process of studying the relationship between a word and a term occupies one of the important places in terminology.

Justifying the opposition of a term and a common word, it is necessary to define the word as a unit of language. A word is the smallest semantic unit of a language that is freely reproduced in speech and used to construct statements [1]. The semantic structure of a word is described by a well-known semantic triangle in linguistics, where an object and a concept are distinguished: the word denotes the object and expresses the concept. However, nominativity cannot be recognized as a feature that separates a term from a word, since nominativity is a property of any language sign. Nominativity means the ability of a language unit to independently express the meaning associated with it regardless of combinations with other units, in distraction from its functionalsyntactic specialization.

In most modern definitions of the term, the function of expressing a special professional concept acts as its main differential feature. A concept is an element of thought that reflects the features, properties, and relationships of displayed objects and phenomena of reality, and identifies the objects and the phenomena of the reality as independent objects [1]. Common words express general ideas or everyday concepts, whereas terms express professional, scientific or technical concepts. Concepts are the result of generalizing items of a certain class by specific characteristics. The following examples illustrate the meaning and the translation of lexical units as common words and as banking terms: 1) accommodation - размещение/housing (a common word), кредит/a credit (a banking term); 2) quotation - цитата/citation (a common word), курс, котировка/a price (a banking term); 3) ladder - лестница/stairs (a common word) многозвеньевая структура/a structure with many units (a banking term); 4) maturity зрелость/adulthood (a common word), срок действия кредита/a loan life (a banking term); 5) parking - парковка/a parking lot (a common word) - временные инвестиции/temporary investments (a banking term).

According to B. N. Golovin, information about logical generalizations of features peculiar to groups of objects with homogeneous features comes to the fore in terms. The emotional sphere of consciousness is not involved in this case. A term is defined as a verbalized result of cognition of a particular special field of knowledge or activity, it represents the structures of special knowledge that determine the cognitive essence of the term [1].

In connection with the deepening of the cognitive orientation of language learning, the task of identifying the types of language signs, the rules of interpretation and conditions for the 
emergence and development of these signs, as well as the principles governing their functioning has arisen. Different types of signs reflect certain aspects of the conceptual picture of the world and, accordingly, different knowledge about the world. It is important to find out what determines the originality of the term from these positions, and what features, properties, and functions distinguish it from other language units.

The most important point in the cognitive study of terms and term systems is defining the central role of a person in the processes of cognition and formation of speech. In light of the cognitive approach to understanding the semantics of words an emphasis should be based on anthropocentrist thinking, language picture of the world language and lexical-semantic variants of the word. It is an indisputable fact that any meaning of the word does not come into the reality in the material form of ready-made knowledge. The meaning is formed only in the mind of the speaker and then the listener [3]. It is a person who acts as an observer and a carrier of certain knowledge and experience, selects language tools for interpreting objects and phenomena of reality, and forms the values of special units [4].

Today, the methods of structural description of terms and term systems have been replaced by methods of cognitive modeling of terminology in order to differentiate the types of knowledge. Thus, under the influence of cognitive linguistics, term studies are aimed at researching the internal, that is, the semiotic nature of the term.

The cognitive approach allows us to reveal the causes and mechanisms of dynamic processes in the field of professional nomination, taking into account the changing cognitive and communication needs of people. In addition, this approach helps to form a more complete and comprehensive view of the term, since it takes into account the prototypical categorization and updating of the term in the field of special communication.

In cognitive terminology, a term is defined as a verbalized result of professional thinking, a means of orientation in the professional sphere, and an important element of professional communication. The term implements the result of cognition of a special area of knowledge that defines the cognitive essence of the term. Moreover, terms perform a communicative function, since they are means of transmitting cognitive knowledge. From a communicative point of view, the term should be compact and convenient for use in professional speech. Due to its concise form, the term is able to convey a fairly large amount of knowledge [5]. For example, the lender's right to enter the premises and to control or remove the tenant's personal property used as collateral for a loan is translated into English by means of a concise phrase "landlor's waiver", or an offer made by the corporation or its agent to purchase shares from odd-lot shareholders and immediately resell them in the market, usually in round-lots to institutions, thus saving the corporation the expense of merely buying shares back is named "odd-lot resale" [6].

The cognitive approach allowed us to talk about the term system not only as a set of terms, but as a grid of knowledge that gives an idea of the entire structure of science, and demonstrates the grounds for identifying the components of the system, their interaction, and the most important principles of organizing the system [5].

The study of term systems using cognitive semantic analysis allows us to more deeply examine the processes of their formation and functioning. The specificity of cognitive semantics lies in the fact that the central place in it is occupied by the anthropocentric factor, that is, a person who, in the process of his cognitive activity and due to cognitive abilities, acts as a 
categorizer and conceptualizer. Human cognitive activity (cognition) is aimed at exploring the world around us and developing the ability to navigate in this world using the knowledge gained, which is inevitably associated with classification activities, that is, the need to identify and compare objects and events. The central place in this classification activity is occupied by the processes of conceptualization and categorization, where the process of conceptualization is aimed at identifying the minimum meaningful units of human experience, and the process of categorization is aimed at combining similar units in categories.

When describing the processes of conceptualization and categorization, it is necessary to define a concept and a category. Concept is a term that serves to explain the units of our consciousness and the information structure that reflects the knowledge and experience of a person; operational content unit of memory, mental lexicon, conceptual system and language of the brain, the whole picture of the world reflected in the human psyche [4]. Concepts represent the meanings that a person uses in the process of thinking, they reflect the experience, knowledge, the result of human activity and processes of knowledge of the world. The emergence of the concept is associated with the need to identify and distinguish objects of the surrounding world in the process of cognitive activity. The concept brings together all the variety of the objects and phenomena being observed and imagined. In each concept, information about the world that is fundamentally important for a person is brought together, and at the same time, non-essential knowledge is discarded.

Cognitive linguistics is primarily concerned with everyday cognition performed by a person in the course of his or her daily activities. For this reason, the concept, which is the central unit of cognitive linguistics, relates mainly to the everyday experience of human interaction with the surrounding reality. Common words reflect everyday knowledge, through which special knowledge itself can be formed. The more structured the special knowledge is, the stronger the connections between terms in the term system are.

The conceptual system is formed at the expense of initial or primary concepts, from which all other concepts are then developed. Concepts are constantly specified and modified under the influence of other concepts. For example, a term "account" is usually translated as "bookkeeper/бухгалтер". On the other hand, when being a part of word combinations, it shows the specification, since it is enriched with additional characteristics: joint account - общий счет, blocked account - замороженный счет, correspondent account - корреспондентский счет, active account - активный счет, deposit account - депозитный счет, savings account сберегательный счет [7, 6].

The system of concepts forms a picture of the world, which reflects a person's understanding of reality, its special conceptual "picture", on the basis of which a person perceives the world [8].

Unlike a notion that reflects the essential features of an object or phenomenon, a concept can reflect any, not necessarily essential, features. The concept is the result of theoretical knowledge, namely the allocation of general, most important characteristics of objects and phenomena. The concept, in turn, is the result of cognition, it is our everyday knowledge. In other words, the terms "a notion" and "a concept" are related as generic and species names. Concept is a mental national-specific unit, where the content is the whole set of knowledge about this object, and the lexical embodiment is a set of language means (lexical, phraseological, etc.). Concepts are not any notions, but only the most complex and important ones, without which it is difficult to imagine this culture. 
A concept has an emotional, evaluative and expressive color; it is a collection of associations, representations, and experiences that accompany the notion that this word expresses. Concepts are more broad in comparison with notions, they are characterized by a more complex system of expression and do not always have complete correspondences in the translation language, so concepts are often translated not just by a word, but by a phrase and even a detailed sentence in order to convey the required meaning most adequately. For example, the verb to puke is translated from English to Russian as "feel seek". In banking terminology, it means "to sell a position on securities with a large loss when the investor has reached the point of complete disgust (puke point) in relation to this paper" [6].

In language a concept is implemented using a language sign, which can act as ready-made phrases, phraseological units, sentences and texts. However, it is important to understand that the same word may show different features of the concept depending on the communicative conditions.

Conceptual analysis, that is the analysis of semantics and word usage, makes it possible to identify the national semantics of this concept and the priority of certain conceptual features. The presence of different definitions in different dictionaries indicates that it is impossible to fully define the content of the concept. Each word represents only a part of conceptual characteristics that are important for communication.

According to E. S. Kubryakova, the concept is extremely important in modern theories of cognition, it occupies the main place in the process of thinking, the processes of conceptualization and categorization of the world [4].

Conceptualization is analyzing the incoming information, the mental construction of objects and phenomena, which leads to the formation of certain ideas about the world in the form of concepts. As mentioned above, concepts do not exist in isolation, they are grouped into categories, forming entire classes of objects. As E. S. Kubryakova puts it "the formation of a category is closely related to the formation of a concept or group of concepts around which it is built, by means of allocating a set of features that express the idea of similarity of the units being combined. The mechanism of categorization should be attributed to the level of the conceptual structure, because judgments about belonging to the same or different categories are the results of comparing two conceptual structures" [4].

To name some object, it is necessary to classify (to categorize) it. Categorization is the division of the world into categories, groups, classes of similar objects or events. Categorization is also a cognitive process, its essence is to correlate items and events with a certain group of similar items and events, namely with a certain category. Thus, the most important function of human consciousness is to divide the world into categories. This process is the basis of all human cognitive activity.

A category is a form of human thinking that allows people to generalize and classify their experience and knowledge. Cognitive science has raised the question of how a person classifies objects and phenomena of reality, how he/she groups the variety of his observations and feelings.

Results and discussion. Numerous studies of language categories formed the basis for the prototype theory and a prototypical approach with the following statements: 1) the real world is structured, and its objects reveal similarities and differences, which allows our consciousness to group these objects into categories; 2) some elements of categories are more significant in comparison with other elements of the same category. This most important element of a category 
is called a prototype. A prototype is a concept that underlies the formation of categories and determines its content; 3 ) other elements that embody all the most characteristic features of this category are grouped around prototypes; 4) the object's belonging to a particular category is determined by its similarity to the prototype, they have common characteristics; 5) categories may not have clear boundaries, and the boundaries between categories may be vague or transitional; 6) the internal structure of the category is not defined by a rigid set of mandatory features, but is characterized by a variety of similar characteristics based on the principle of family relationship, where the most significant features are those that are characteristic of the prototype and are common to all members of this category. For example, for the "bank" category this is a company that specializes in accepting deposits, lending, making payments and other financial transactions [7]; "a place for money": 1) "business that keeps and lends money and provides other financial services: "We have very little money in the bank" [9]; 2) "a financial institution that people or businesses can keep their money in or borrow money from: "Marge works for the Royal Bank of Scotland" [10]. For the "money" category this is 1) everything that is a generally accepted measure of value, a means of payment, circulation, accumulation; in modern conditions money is mainly in the form of paper, coins, balances in banks and other credit and financial institutions; 2) amounts of money, funds [6]; 3) what you earn by working and can use to buy things. Money can be in the form of notes and coins or cheques, and can be kept in a bank; 4) someone's wealth, including all the property and other things they own: "The family made their money in the woolen trade" [9]; 5) what you earn, save, invest and use to pay for things: "The business has made more money this year" [10].

Categorization is determined not by the conditional nature of the boundaries between objects and phenomena of the world around, but by various cognitive abilities of the human mind. Cognitive categories are linked to conceptually defined prototypes that are crucial for the formation of categories. The internal structure of the category is highly complex due to the fact that it includes a large number of elements that show different degrees of manifestation of typical features.

On the one hand, having the largest number of characterising features, the central elements of prototypical categories make the category logical, understandable and convenient, since all members of the category meet a given list of characteristics. On the other hand, prototypical categories possess flexibility, which is necessary for human thinking in order to work effectively. Constantly changing knowledge of the world allows to include new elements in categories, even if these elements and the prototype have only a few features in common. Practical experience shows that in the real world there are almost no elements with a perfect combination of mandatory features.

Conclusion. Summing everything up it is possible to conclude that the prototypical approach radically changes the previously existing ideas about the ability of a person to categorize the terms. Researching the processes of categorization of terms can be considered as a type of conceptual analysis, since this approach allows to identify various characteristics of concepts that are the basis of the meaning formation, but are not always obvious from the meaning of the word, and reveal themselves only at the functional level, namely in the statement. At the same time, studying the principles and mechanisms of categorization of the language units makes it possible to identify and analyze their prototypical semantics in terms of their common properties with the prototype of the category. This feature is particularly important for research in cognitive linguistics, since it is the prototypical semantics of language units that largely determine their use in a sentence to convey a particular meaning. The analysis of prototypical 
semantics also provides a deeper understanding of the structure and content of concepts that underlie the formation of language categories, the principles of organization of these categories, and the mechanisms of interaction between cognitive and language structures in the process of forming the meaning of a statement.

\section{REFERENCES}

1. Golovin, B.N. (1987), Lingvisticheskie osnovy ucheniya o terminakh [Linguistic basis of the doctrine of terms], Vysshaja shkola, Moscow, USSR.

2. Lejchik, V.M. (2009), Terminovedenie: predmet, metody, struktura [Termology: subject, methods, structure], 4th ed., Publishing house "LIBROKOM", Moscow, RUS.

3. Kiseleva, S.V. (2010), "Cognitive aspects of a polysemantic word", Cognitive studies of language, vol. 6, pp. 306-308.

4. Kubryakova, E.S., Dem'yankov, V.Z., Pankrats, Yu.G. and Luzina, L.G. (1996), Kratkij slovar' kognitivnyh terminov [A concise dictionary of cognitive terms], in Kubrjakova, E.S. (ed.), Lomonosov Moscow State University, Moscow, RUS.

5. Novodranova, V.F. (2013), "Development of cognitive terminology in Russia at the beginning of the XXI century", Cognitive studies of language, vol. 15, pp. 92-100.

6. Fedorov, B.G. (2011), Novyj anglo-russkij bankovskij i investicionnyj jenciklopedicheskij slovar' [New English-Russian banking and investment encyclopedic dictionary], vol. 2, Limbus Press, SPb., RUS.

7. Fedorov, B.G. (2011), Novyj anglo-russkij bankovskij i investicionnyj jenciklopedicheskij slovar' [New English-Russian banking and investment encyclopedic dictionary], vol. 1, Limbus Press, SPb., RUS.

8. Nil'sen, E.A. (2010), "Concept as a basic concept of cognitive linguistics", Homo Loquens: Actual issues of linguistics and methods of teaching foreign languages, vol. 2, pp. 24-32.

9. Dictionary of contemporary English (2009), New edition. Pearson Education Limited, available at: https://www.Idoceonline.com/ (accessed 10.10.2019).

10. Macmillan Dictionary Online, available at: http://www.macmillandictionary.com/dictionary/british/ money (accessed 10.10.2019).

\section{Information about the authors.}

Svetlana V. Kiseleva - Dr. Sci. (Philology) (2007), Professor at the Department of the Theory of Language and Translation, Saint Petersburg University of Economics, 21 Sadovaya str., St Petersburg 191023, Russia. The author of 150 scientific publications. Area of expertise: terminology, semantics, stylistics, theoretical grammar. E-mail: svkiseljeva@bk.ru

Marina Yu. Mironova - Can. Sci. (Philology) (2019), Senior Lecturer at the Department of English Language № 2, Saint Petersburg University of Economics, 21 Sadovaya str., St Petersburg 191023, Russia. The author of 23 scientific publications. Area of expertise: terminology, semantics. ORCID: https://orcid.org/0000-0002-7938-6254. E-mail: mkpr@yandex.ru

Nella A. Trofimova - Dr. Sci. (Philology) (2009), Professor at the Department of Foreign Languages, Higher School of Economics, Souza Pechatnikov str. 16, St Petersburg 190008, Russia. The author of 122 scientific publications. Area of expertise: semantics, stylistics, theoretical grammar. E-mail: nelart@mail.ru

\section{СПИСОК ЛИТЕРАТУРЫ}

1. Головин Б. Н. Лингвистические основы учения о терминах. М.: Высшая школа, 1987.

2. Лейчик В. М. Терминоведение: предмет, методы, структура. 4-е. изд. М.: Книжный дом «ЛИБРОКОМ», 2009. 
3. Киселева С. В. Когнитивные аспекты многозначного слова // Когнитивные исследования языка. 2010. № 6. С. 306-308.

4. Краткий словарь когнитивных терминов / Е. С. Кубрякова, В. З. Демьянков, Ю. Г. Панкрац, Л. Г. Лузина / под общ. ред. Е. С. Кубряковой; филол. ф-т МГУ им. М. В. Ломоносова. М., 1996.

5. Новодранова В. Ф. Развитие когнитивного терминоведения в России в начале XXI века // Когнитивные исследования языка. 2013. Вып. 15. С. 92-100.

6. Федоров Б. Г. Новый англо-русский банковский и инвестиционный энциклопедический словарь: в 2 т. СПб.: Лимбус Пресс, 2011. Т. 2.

7. Федоров Б. Г. Новый англо-русский банковский и инвестиционный энциклопедический словарь: в 2 т. СПб.: Лимбус Пресс, 2011. Т. 1.

8. Нильсен Е. А. Концепт как базовое понятие когнитивной лингвистики // Homo Loquens: Актуальные вопросы лингвистики и методики преподавания иностранных языков: сб. науч. ст. СПб., 2010. Вып. 2. С. 24-32.

9. Dictionary of contemporary English. New edition. Pearson Education Limited. 2009. URL: https://www.Idoceonline.com (дата обращения: 10.10.2019).

10. Macmillan Dictionary Online. URL: http://www.macmillandictionary.com/dictionary/ british/money (дата обращения: 10.10.2019).

\section{Информация об авторах.}

Киселёва Светлана Владимировна - доктор филологических наук (2007), профессор кафедры теории языка и переводоведения Санкт-Петербургского государственного экономического университета, ул. Садовая, д. 21, Санкт-Петербург, 191023, Россия. Автор 150 научных публикаций. Сфера научных интересов: терминология, семантика, стилистика, теоретическая грамматика. Email: svkiseljeva@bk.ru

Миронова Марина Юрьевна - кандидат филологических наук (2019), старший преподаватель кафедры английского языка № 2 Санкт-Петербургского государственного экономического университета, ул. Садовая, 21, Санкт-Петербург, 191023, Россия. Автор 23 научных публикаций. Сфера научных интересов: терминология, семантика. ORCID: https://orcid.org/0000-0002-7938-6254.Email:mkpr@yandex.ru

Трофимова Нэлла Аркадьевна - доктор филологических наук (2009), профессор департамента иностранных языков Высшей школы экономики, ул. Союза Печатников, д. 16, Санкт-Петербург, 190008, Россия. Автор 122 научных публикаций. Сфера научных интересов: семантика, стилистика, теоретическая грамматика. Email: nelart@mail.ru 